\title{
Motivational changes of learners in a traditional context of English education: A case study of high school students in Iran
}

Kiany, Gholam Reza

English Department, Tarbiat Modares University, Tehran, Iran (rezakiany@yahoo.com)

Mahdavy, Babak $\square$

English Department, Tarbiat Modares University, Tehran, Iran (babakmahdavy@yahoo.com)

Ghafar Samar, Reza

English Department, Tarbiat Modares University, Tehran,Iran (rgsamar@modares.ac.ir)

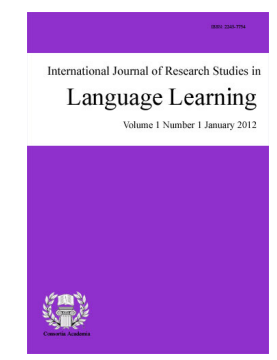

ISSN: $2243-7754$ Online ISSN: 2243-7762

OPEN ACCESS

\section{Abstract}

One of the underexplored areas of research within the language learning literature has been investigating the role of various contextual factors which affect second/foreign language motivation. Since foreign language teaching in Iran is relatively unique in terms of teaching and learning environment, the present study examined the combined effects of these contextual characteristics on the motivational changes of students after four years of learning English at high schools. The data was collected by administering a valid and reliable questionnaire which measured 'L2 Motivational Self System' of 401 Iranian high school students. Results of descriptive statistics showed that all the motivational variables decline during the last years of high school English language teaching and only 'L2 anxiety' increases. According to the results of Mann-Whitney-Wilcoxon test, the declines in 'interest', 'ideal L2 self' and 'instrumental-promotion' are statistically significant. The study concluded that these changes in students' motivation are due to the effects of the traditional teaching and learning environment and conservative policies of foreign language teaching. Obviously, increasing learner motivation in this context of English teaching requires scientific reforms within the educational system.

Keywords: Second/foreign language teaching; L2 motivational self system; Iranian high schools; case study 


\section{Motivational changes of learners in a traditional context of English education: A case study of high school students in Iran}

\section{Introduction}

In both general and second/foreign language education the relationships between the context of teaching and learning and learner motivation have been discussed. Some of these discussions have focused on the psychological and social characteristics of teaching and learning (e.g. McRobbie \& Tobin, 1995; Schmuck \& Schmuck, 2001; Tobin \& Mcrobbie, 1996), classroom management (Jones \& Jones, 2000) and more specifically learner autonomy (Deci \& Ryan, 1985; Philippe \& Vallerand, 2008). A relatively comprehensive model of foreign language learning motivation which includes contextual variables was proposed by Dörnyei (1994). According to this model, the three levels of motivation which include language, learner and learning situation interact to increase or decrease the total amount of motivation generated in the context of a foreign language classroom. Within the model the learning situation level is further divided into course-specific, teacher-specific and group-specific components which are concerned with 'interest', 'relevance', 'expectancy', 'satisfaction', 'facilitative drive', 'authority type', 'direct socialization of motivation', 'goal-orientedness', 'norm and the reward system', 'group cohesion' and 'classroom goal structure' as the variables which affect the rate of motivation induced by learning situation. In addition, Legenhausen (1999) emphasized the role of using authentic L2 communication in engaging learners' internal selves which is also believed to contribute to learner motivation (Ushioda, 2011). In spite of such debates, however, as it was suggested by Hickey and McCaslin (2001) the relationships between contextual factors and learner motivation have not been thoroughly explored.

The Iranian context of English language teaching at high school is an example of an environment in which the Grammar-Translation method is utilized predominantly and foreign language teaching is not always recognized as an instrument for development. In fact it has been claimed that Iran has opted for a different foreign language education policy as unlike many countries such as China, South Korea and Japan, foreign language teaching is viewed more conservatively (Farhady, Hezaveh, \& Hedayati, 2010). With these environmental characteristics it is expected that foreign language motivation in Iranian high schools can be impacted by the contextual variables which may positively or negatively contribute to each type of learner motivation. In order to deal with the issue, we have therefore decided to collect empirical information about learner motivation in this context and examined changes in the motivation of learners who stay in the educational system during the four years of high school education. We have, therefore, formulated the following research questions:

1. What are different types of motivation English language learners have for learning English at high schools in Iran?

2. Are there changes in the students' level of motivation over the four years of high school English language learning in Iran?

\section{Literature review}

\subsection{Second/Foreign Language Learning Motivation}

From 1960 to 1990 much of L2 motivation research can be attributed to Gardner and Lambert who distinguished between the integrative and instrumental orientation for L2 learning. According to the two Canadian psychologists' socio-psychological approach, integrative orientation is as an orientation to adopt certain behaviors characteristic of the target cultural group while instrumental orientation emphasizes the 
practical values of learning a language. They also indicated that integrative orientation is necessary for higher levels of L2 achievement (e.g. Gardner, 1985; Gardner \& Lambert, 1972). Results of a study conducted by Gardner, Smythe, Clément, and Gliksman (1976) showed that integrative orientation is especially important for the acquisition of communicative language skills. In the 1990s, however, the integrative/instrumental dichotomy was criticized for emphasizing the social milieu dimensions of L2 motivation and not focusing on foreign language classroom (e.g. Dörnyei , 1994). In addition, it was argued that in the case of learning a lingua franca such as English it is not appropriate to refer to the native speakers as the owners of the language (Coetzee-Van Rooy 2006; Lamb 2004). Dörnyei (1994) also suggested that the integrative/instrumental model is of little use for foreign language learners who may never have the opportunity to communicate with the native speakers of the language. In order to respond to these theoretical and practical shortcomings, alternative models of L2 motivation were proposed to complement the instrumental/integrative dichotomy (e.g. Crooks \& Schmidt, 1991; Tremblay \& Gardner, 1995). One of these reconceptualizations was provided by Noels, Pelletier, Clément, and Vallerand (2000) who advocated four orientations including travel, friendship, knowledge and instrumental orientation in motivation research. Dörnyei (2000) proposed a process-oriented approach to the conceptualization of L2 motivation and showed that the initial wishes and desires turn into goals and then operationalized intentions which are enacted to achieve the goals. The final stage in this process is evaluation.

In 2005, Dörnyei provided a new theory of L2 motivation calling it the 'L2 Motivational Self System'. The model which tries to address the major shortcomings of Gardner and Lambert's integrative/instrumental theory of L2 motivation can be regarded as one of the recent major developments in second language motivation research. According to this model, integrativeness is redefined as an internal process of identification within a learner's self-concept rather than his/her identification with an external reference group. The model which was inspired by the psychological theory of 'possible selves' (e.g. Higgins, 1987; Markus \& Nurius, 1986) established a link between the self-concept and motivation. Dörnyei and Ushioda (2009) illustrated the main components of the 'L2 Motivational Self System' as follows:

1. Ideal L2 Self, which links the L2 specific facet of one's 'ideal self': if the person we would like to become speaks an L2, the 'ideal L2 self' is a powerful motivator to learn the L2 because of the desire to reduce the discrepancy between our actual and ideal selves. Traditional integrative and internalized instrumental motives would typically belong to this component.

2. Ought-to L2 self, which concerns the attributes that one believes one ought to possess to meet expectations and avoid possible negative outcomes. This dimension corresponds to Higgins's ought self and thus to the more extrinsic (i.e. less internalised) types of instrumental motives.

3. L2 Learning Experience, which concerns situated, 'executive' motives is related to the immediate learning environment and experience (e.g. the impact of the teacher, the curriculum, the peer group, the experience of success). This component is conceptualized at a different level from the two self-guides and future research will hopefully elaborate on the self aspects of this bottom-up process. (p. 29)

The relationships between the new motivations construct and integrative/instrumental conceptualization was investigated by examining the correlations between integrativeness, 'ideal L2 self', 'instrumentality' and 'ought-to L2 self' (Taguchi, Magid, \& Papi, 2009). The study which used Higgins's (1987, 1998) promotion/prevention distinction to interpret the obtained data reported higher correlations between 'ideal L2 self' and 'instrumental-promotion' than with 'instrumental-prevention'. However, higher correlations were found between 'ought-to L2' self and 'instrumentality-prevention' type of motivation. The magnitude of correlations between integrativeness and 'ideal L2 self' was also found to be large. The results caused the researchers to conclude that the traditional instrumental motivation includes the two separate dimensions of promotion and prevention and that integrativeness and 'ideal L2 self' are two closely related concepts.

Most of the L2 motivation studies in Iran have followed the integrative/instrumental tradition. Results of a 
study by Dastgheib (1996) showed that there is a statistically significant and positive correlation between attitudes towards learning English and desire to learn it. The participants of the study who were university undergraduate students studying in different fields of medicine were also assessed in terms of their motivation to learn the English language and results of correlation analysis indicated that both students' attitudes and their desire positively correlated with integrative motivation and motivational intensity. According to Sadighi and Maghsudi (2000), integrative motivation in comparison to instrumental motivation has a more important role in the TOEFL performance of undergraduate students majoring in Teaching English as a Foreign Language (TEFL) in Iran. Matin (2007) did not find a significant difference between integrative and instrumental orientation among University students in Tehran. Vaezi (2009), however, suggested that students in Birjand University in Iran were more instrumentally motivated than integratively motivated to learn English. The study, however, did not report the reliability and validity of the instrument which was used for measuring the participants' motivation. Farhady (2006) who used random cluster sampling procedure to select the participants from 20 educational districts in Tehran found that the rate of attitudes, motivation, self-confidence in addition to the amount of time students spend trying to learn English generally decreased from grade 2 to grade 3 in junior high schools.

Recently, at least two studies investigated L2 motivation among English language learners in Iran utilizing the 'L2 Motivational Self System' model. Part of a research study carried out by Taguchi et al. (2009) focused on the investigation of a number of motivational factors including 'criterion measures', 'ideal L2 self', 'ought-to L2 self', 'family influence', 'instrumentality-promotion', 'instrumentality-prevention', 'attitudes to learning English', 'cultural interest', 'attitudes to L2 community' and 'integrativeness' in the Iranian context. In this study a motivation questionnaire consisting of 76 items was used to obtain data from 2029 English language learners in Iran. The results showed that instrumentality-promotion and 'ought-to L2 self' tend to have a relatively high correlation in the Iranian context. The researchers related the findings to the fact that in Iran knowledge of English is associated with the socio-economic situation of individuals. Papi (2010) examined the relationships between L2 motivational self system, 'L2 anxiety', and motivated behavior among the Iranian high school students by using structural equation modeling. The results revealed the significant contributions of all the variables in the study to intended effort. It was also shown that 'ideal L2 self' and the 'L2 learning experience' decrease 'L2 anxiety' while 'ought-to L2 self' significantly contribute to learner anxiety.

Previous studies have also discussed the role of different de-motivating factors for English language learning. Some of these factors include characteristics of teachers (Gorham \& Christophel, 1992), classroom environment (Falout \& Maruyama, 2004), teaching and learning materials (Kikuchi \& Sakai, 2009) and lack of self-confidence (Dörnyei, 2001). Given the fact that each of these factors can be regarded as one of the components of any educational program including high school English language teaching curriculum of Iran, it might be interesting to see the combined effects of these variables by examining motivational changes of English learners in the local context.

\subsection{Policies of Foreign Language Education in Iran}

Policy setting is an important part of designing a foreign language education program. Influenced by social, economic and political changes in the globalized world, different countries have decided to examine the effects of previous standards in various areas. One consequence of such decisions has been attempts to redefine foreign language teaching in the national curriculum of many countries. Kirkgöz (2009) posited that the unprecedented spread of English as a lingua franca along with globalization have had their own effects on the way English is being viewed and taught in different countries. Dörnyei and Csizér (2002) investigated language-related motivation and attitudes of Hungarian pupils and showed that between 1993 and 1999 there was a significant decline in the learners' motivation to learn German, French, Italian and Russian but the results indicated that only English maintained its position. They finally concluded that the results of the survey should be interpreted in the context of socio-cultural changes which happened in the country in the 1990s and argued that the changes reflect the process of 'language globalization' in Hungary. Wang and Lam (2009) noted that the Tiananmen incident and disintegration of the Soviet Union made China revise its modernization policies to become a more 
independent country. Consequently, ELT became a tool for China to play a more active role in the global economy not a tool for Westernization. According to Kirkgoz (2007), as part of the Turkey's attempts to become a member of the European Union, the country has recently updated the 1997 educational reform by providing a more detailed description of the curriculum contents and specifying the appropriate forms of assessment. Kirkgoz (2007) further indicated that at the lower levels learner attitudes, motivation, appropriate use of strategies and meaningful learning of language through games and contextualization are some of the stated objectives of the new curriculum and at higher levels the goal is the development of the learners' communicative capacity.

A historical account of four language stages in Iran was provided by Riazi (2005). He suggested that 'Old Persian' was spoken in the Persian Empire predominantly. During the Islamic era Arabic influenced the Persian language and in the last 150 years Western 'language and culture' was introduced. And the fourth stage focused on the negative effects of the Western identity after the Islamic revolution. Riazi (2005) concluded that the process of globalization generates an economic power which imposes English language use in spite of the formal policies developed for the school curricula. Such a change in the formal policies, however, has not happened yet as it was indicated by Farhady et al. (2010) that although countries such as Hong Kong, India, Japan and China regard English as an important instrument helping them join the international world of commerce, Iran fears that the negative effects of the foreign language may finally turn into a threat to the national and religious identity of people and the Persian language. They further noted that the present situation is a consequence of politicising English after the Islamic revolution.

Therefore, we may conclude that English teaching policies in Iran are currently different from those of many other countries in the world because the attitudes towards the teaching of foreign languages including English have not been quite positive especially during the past 30 years. As a consequence, the same formal policies continue to be implemented. Obviously these English teaching policies which reflect the attitudes towards the teaching of the language constitute an important aspect of the English teaching context at high schools in Iran.

\subsection{Foreign Language Education in Iran}

In today's Iran education is highly centralized. Primary education (Dabestan) starts at the age of 6 and continues for 5 years. Students who enter the middle school (Rahnamayie) will spend three years after which they go to high school (Dabirestan). High school education which goes from the $9^{\text {th }}$ to the $12^{\text {th }}$ grade is divided into theoretical, technical and vocational branch. It starts with the first year in general studies and includes many different courses such as Persian, Mathematics, Foreign Languages, Theology, Chemistry, etc. Students proceed to the second year upon passing the final exams of the first year. The second and third grades focus on a subject area and finally a diploma is awarded to the students who perform successfully on the third-grade exam. Students who take the technical/vocational path receive a vocational diploma which qualifies them to work in their area of specialization. The last year of education in Iran is named the pre-university (Pish-daneshgahi). It is a 1-year intensive program helping students qualify for higher education. Recently Supreme Council of Cultural Revolution has passed a law according to which pre-university should be removed from the educational system over the next years.

Farhady et al. (2010) suggested that the French language gained a social prestige in Iran because in 1839 a French priest came to establish the first modern school in the country. However, after World War II and during the Pahlavi dynasty (1925-1979) in Iran because of close political, social, economic and military relations between Iran and the United States, English finally became a social need and thousands of students learned the language in order to be able to study in American universities. After the Islamic revolution, however, the relations between Iran and the English-speaking countries deteriorated and English was viewed as a threat to the identity of Iranians (Farhady et al., 2010).

Within the educational system of Iran English is taught four hours a week at junior high schools and two 
Kiany, G. R., Mahdavy, B., \& Ghafar Samar, R.

hours per week at senior high schools. The system is basically exam-based and the national exams including the English section of University Entrance Examination (UEE) determine the norms for the teaching and learning of the language. According to Riazi and Mosalanejad (2010) teachers feel responsible to prepare students for the high stakes multiple-choice exams. The following is Namaghi's (2010) description of a typical high school English language class and contextual variables` in the urban areas of a province in the eastern part of Iran:

"Nearly thirty students sit in rows facing the blackboard. A ninety minute class is mainly teacher-fronted, and teacher centered. Lecturing is the rule, though there may be occasional variation on the part of novice teachers. Learning activities are text-centered. Teachers' main concern is coverage rather than responsive teaching. Similarly, students' main concern is passing the final exams and scoring high rather than learning English. Thus responses to the questions about the text tend to consist of relevant passages quoted from the text. A limited version of Grammar Translation Method (GTM) is the best guarantee for teachers to cover the material in the pre-specified time-line, and an efficient method of helping students score high in the finals since oral skills are totally ignored in the finals. Since final exams cover reading comprehension, vocabulary and grammar, teachers' main tasks are: providing Persian equivalents for new words, translating the text, making the students translate, explaining grammar, and making students do written exercises at home, and finally giving feedback on the accuracy of their answers... ” (p. 217).

\section{Method}

\subsection{Participants}

Four hundred and one Iranian high school students consisting of 305 female and 96 male first, second, third and fourth-graders were the participants of the study. The number of the participants in terms of their field of study at high school was as follows: General (for the first graders): 46; Mathematics: 98; Natural Sciences: 100; Humanities: 63 and Vocational and Technical branch: 94. The participants whose age range was between 14-18 years old were selected from public high schools in the Northern Province of Iran, Mazandaran. The schools were all located in the semi-privileged areas. Convenience sampling was used to select the participants and as Table 1 shows, in order to have a more representative sample, attempts were made to select them from various sub-groups.

\section{Table 1}

Distribution of the sample by gender, grade and field of study $(N=401)$

\begin{tabular}{llll}
\hline & \multicolumn{1}{c}{ Gender } & \multicolumn{1}{c}{ Grade } & \multicolumn{1}{c}{ Field of study } \\
\hline High school students & Female: 305 & First: 46 & General: 46 \\
& Male: 96 & Second: 200 & Mathematics: 98 \\
& & Third: 93 & Natural science: 100 \\
& & Fourth: 62 & \\
\hline
\end{tabular}

\subsection{Instrumentation}

The L2 motivational self system introduced by Dörnyei $(2005,2009)$ was the theoretical framework utilized to prepare an instrument for investigating students' motivational changes over the four years of high school foreign language education. The questionnaire consisted of 40 6-point Likert scale items and included both statement-type and question-type scales. The items were selected from the L2 motivation questionnaire developed in Persian by Taguchi et al. (2009). Construct validity of the questionnaire was checked by performing principle component analysis using varimax rotation (see Appendix). The analysis yielded seven factors which explained $57.51 \%$ of the total variance. And Kaiser-Meyer-Olkin and Bartlett's test verified the assumptions of 
component analysis $(\mathrm{KMO}=.92, \mathrm{Sig}=.00)$. Since the same validation procedure which included all the motivational variables in the analysis was not originally used for the construction of the questionnaire, item loadings reflected changes in the number of variables which is explained below. The theoretical definitions and results of item loadings were used to come up with the following classification and definitions:

1. Interest: It is students' interest in the immediate English learning environment and the experience of learning. It also shows the amounts of efforts students are ready to make in order to learn English. Many items of this part were taken from the 'English learning experience' and 'intended efforts' (Papi, 2010; Taguchi et al., 2009) section of the original questionnaire. The items of the variables, however, loaded on the same factor. The fact that the two variables can be reduced to one variable also finds support in Papi (2010) who found the strongest associations between 'intended efforts' and 'English learning experience' using structural equation modelling. One of the three items related to 'intergrativeness', item 39, also loaded under 'interest'. The other two items were excluded because they were not able to load as a separate variable or under any of the study variables. Except for these two items, none of the items appearing in the original questionnaire were removed as all the 13 items loaded on the same component which was named 'interest'.

2. Ought-to L2 self: According to Dörnyei (2005), it measures the attributes that one believes one ought to possess (i.e. various duties, obligations, or responsibilities) in order to avoid possible negative outcomes. This kind of motivation concerns the motivation caused by the peers, parents, friends and relatives. Items 19 which was included in the 'family influence' section of the original questionnaire loaded under 'ought-to L2 self' apparently because both variables describe the motivation induced by others. Item 23 which loaded on 'ought-to L2 self' was one of the items in the 'instrumental-prevention' section of the original questionnaire. This pattern of item loading is not surprising as empirical information obtained in previous research has shown that in Japan, China and Iran 'family influences and the prevention-focused aspects of instrumentality (e.g. learning the language to avoid failing an exam) impinge upon this variable [ought-to L2 self]' (Papi, 2010, p. 469). Two of the items in the original questionnaire which were supposed to measure 'ought-to L2 self', however, were excluded because they did not emerge as a separate component and did not have loadings above 30 .

3. Cultural orientations towards L2 community: It is a combination of 'attitudes to L2 community' and 'cultural interest' in the original questionnaire (Dörnyei, 2005). It shows both learners' attitudes towards the community of English speakers and their interest in L2 cultural products such as TV, movies, music, etc. Three of the items which were related to these two categories in the original questionnaire did not have loadings above .30 and were therefore removed. As a result, the total number of items for this section of the questionnaire was five.

4. Ideal L2 self: It refers to the students' imaginations of their ideal selves and the extent to which its realization depends on L2. Three of the items of 'ideal L2 self' in the original questionnaire did not load on any single variable and therefore were excluded. However, item 4 and 20 which appeared under 'travel orientation' and 'instrumental-promotion' component in the original questionnaire loaded under 'ideal L2 self'. This can be easily justified as both items describe learners' imagined selves. With the removal of the two items associated with 'travel orientation' due to their insignificant loadings, this variable was excluded from the study.

5. Instrumental-promotion: It is concerned with the degree to which learners associate L2 with their positions in family and society. It is also related to the degree to which knowledge of English is connected with the kind of job learners can find and/or amount of salary they can receive. Item 1 and 6 which were associated with 'family influence' loaded under 'instrumental-promotion' scales. Item 2, 7, and 13 of the questionnaire focused on aspects of motivation which were concerned with students' 
future jobs, salary, educational degree, etc. Two of the items in the 'instrumental-promotion' section of the original questionnaire were excluded because of exhibiting insufficient loadings.

6. L2 Anxiety: According to a definition by MacIntyre and Gardner (1994) 'L2 anxiety is associated with the use of second language while speaking, listening, and learning'. The items which loaded on this component focused on the anxiety created in contexts of foreign language use. Since three of the six items which were included in the 'L2 anxiety' section of the original questionnaire did not have loadings above .30 , they were excluded.

7. Instrumental-prevention: It refers to the motivation caused by obligations and duties such as passing examinations, getting a degree, etc (Taguchi et al., 2009). Four of the 'instrumental-prevention' items did not load significantly under one of the components and therefore were excluded. One of the items also loaded on 'ought-to L2 self' which was explained above.

Since there have been no research studies reporting the results of principle component analysis of the 11 variables together, this procedure was used to validate the questionnaire data. The loss of 21 items after using principle component analysis in addition to the changes of item loadings showed that the 11 variables should be reduced to seven main variables.

The reliability of the instrument was also checked using Cronbach Alpha reliability. Information regarding the seven components, the number of items appearing under each factor and reliability of the results are presented in Table 2:

Table 2

Composites of motivational variables with Cronbach Alpha reliability

\begin{tabular}{lcc}
\hline \multicolumn{1}{c}{ Factors } & Number of items & Reliability \\
\hline Interest & 13 & 0.92 \\
Ought-to L2 self & 6 & 0.76 \\
Cultural orientations & 5 & 0.80 \\
Ideal L2 self & 5 & 0.80 \\
Instrumentality-promotion & 5 & 0.73 \\
L2 anxiety & 3 & 0.71 \\
Instrumentality-prevention & 3 & 0.60 \\
\hline
\end{tabular}

\subsection{Procedure}

The data related to the students L2 motivation was collected by making personal contacts with teachers who volunteered to administer the motivation questionnaire in different schools. The teachers were given the necessary instructions for questionnaire administration. As it was reported by the teachers, students took almost 15 minutes on average to respond to the questionnaire items. The participants' responses to each group of items which appeared under each of the seven components were added up and then the raw scores were converted into percentage data.

\section{Data Analysis and Results}

The first question formulated in the present study concerned different types of motivation students have for learning English at high schools. In order to answer the question, descriptive statistics of the data which had been imported into SPSS 18.0 was calculated using the statistical software. As Table 3 shows, 'instrumental-promotion' and 'instrumental-prevention' have the highest means. 'Ideal L2 self' is the third motivational variable with a relatively high mean and as the mean of students' responses indicate, in general they have positive 'cultural orientations towards L2 community'. And 'interest', 'L2 anxiety' and 'ought-to L2 self' are the three variables with the lowest means. 
Motivational changes of learners in a traditional context of English education

Table 3

Descriptive statistics of motivational variables $(N=401)$

\begin{tabular}{lcccc}
\hline \multicolumn{1}{c}{ Factors } & Mean & $S D$ & Min. & Max. \\
\hline Interest & 67.83 & 18.92 & 19.23 & 98.72 \\
Ought-to L2 self & 58.61 & 17.77 & 16.67 & 94.44 \\
Cultural orientations & 70.12 & 20.60 & 16.67 & 100.00 \\
Ideal L2 self & 73.61 & 19.02 & 16.67 & 100.00 \\
Instrumental-promotion & 76.51 & 16.28 & 26.67 & 100.00 \\
L2 anxiety & 60.46 & 19.59 & 16.67 & 100.00 \\
Instrumental-prevention & 74.90 & 18.54 & 16.67 & 100.00 \\
\hline
\end{tabular}

In the next stage the study focused on high school students' L2 motivational changes. In other words, we examined the impact of the educational system on English language learners' motivation by comparing the level of each L2 motivational variable among the first and second graders with the amount of each motivation among the third and fourth graders at high school. The participants in this stage were, therefore, divided into two groups. The first group was comprised of first and second year students and the second group included students in the third and fourth grade of high school. The two groups were compared in terms of their responses to the items related to each motivational scale. Table 3 provides descriptive statistics of students' performance and shows that there is a systematic decline in almost all the variables as students approach the last years of their high school education. The only variable which increased among the third and fourth graders was 'L2 anxiety'.

Table 4

Descriptive statistics of motivational variables by group $(N=401)$

\begin{tabular}{lcccc}
\hline \multicolumn{1}{c}{ Factors } & Group & $n$ & Mean & $S D$ \\
\hline Interest & 1 & 265 & 69.94 & 1.13 \\
\multirow{2}{*}{ Ought-to L2 self } & 2 & 136 & 63.71 & 1.64 \\
\multirow{2}{*}{ Cultural orientations } & 1 & 265 & 59.16 & 1.08 \\
& 2 & 136 & 57.53 & 1.55 \\
Ideal L2 self & 1 & 265 & 70.44 & 1.31 \\
& 2 & 136 & 69.77 & 1.63 \\
Instrumental-promotion & 1 & 265 & 75.96 & 1.10 \\
& 2 & 136 & 69.04 & 1.72 \\
L2 anxiety & 1 & 265 & 78.77 & 0.96 \\
& 2 & 136 & 72.10 & 1.43 \\
Instrumental-prevention & 1 & 265 & 59.30 & 1.17 \\
& 2 & 136 & 62.70 & 1.73 \\
& 1 & 265 & 75.68 & 1.13 \\
& 2 & 136 & 73.40 & 1.60 \\
\hline
\end{tabular}

Note. $1=$ first and second graders; $2=$ third and fourth-graders

Although the descriptive statistics in the table shows that there were differences between the performances of students in the two groups, it is not known whether the differences are statistically significant or not. Results of Shapiro-Wilk showed that normality assumptions were violated $(p<0.05)$. Therefore, Mann-Whitney-Wilcoxon, which is a non-parametric test for comparing the performance of two independent groups, was utilized to see whether there was any statistically significant difference in the variables under study.

As Table 4 shows, the differences between the two groups in terms of 'interest', 'ideal L2 self' and 'instrumental-promotion' were found to be statistically significant. However, the two groups did not differ in terms of 'ought-to L2 self', 'cultural orientations towards the L2 community' and 'instrumental prevention' in a statistically significant way. The increase in 'L2 anxiety' was not statistically significant. 
Kiany, G. R., Mahdavy, B., \& Ghafar Samar, R.

\section{Table 5}

Mann-Whitney-Wilcoxon test for comparing the two groups in terms of motivational changes

\begin{tabular}{lccc}
\hline \multicolumn{1}{c}{ Factors } & Mann-Whitney & Wilcoxon & Asymptotic Significant \\
\hline Interest & 14360.5 & 23676.5 & $0.00^{* *}$ \\
Ought-to L2 self & 17327.5 & 26643.5 & 0.52 \\
Cultural orientations & 17259.0 & 26578.5 & 0.48 \\
Ideal L2 self & 14377.0 & 23693.0 & $0.00^{* *}$ \\
Instrumental-promotion & 13508.5 & 22824.5 & $0.00^{* *}$ \\
L2 anxiety & 16832.5 & 52077.5 & 0.27 \\
Instrumental-prevention & 16484.5 & 25800.5 & 0.16 \\
\hline Note. **Significant differences between the two groups $(p<.01)$ & &
\end{tabular}

\section{Discussion}

The present study aimed to examine learner motivation and motivational changes within the traditional context of English language education at high schools in Iran. The first question of the research was addressed by measuring the total amount of each type of motivation among high school students regardless of the high school grade. According to the results, 'instrumental-promotion' is the strongest type of motivation among high school students. This finding suggests that students highly associate English with their success in the future. However, as the result of analyzing motivational changes indicated, one of the largest and statistically significant declines in the last years of high school English teaching is in the rate of 'instrumental-promotion'. Similar decreases can be also found in 'interest' and 'ideal L2 self' which are both relatively more internal sources of L2 motivation. Since the traditional Grammar-Translation approach to the teaching of English (e.g. Namaghi, 2010) in addition to the conservative policies of foreign language teaching (e.g. Farhady et al., 2010) are the two salient features of the context of foreign language education in Iranian high schools, we may conclude that these contextual variables are the main cause of the declines in learner motivation especially in the kinds which are more internal. In other words, the ELT curriculum seems to be able to have students perceive English as an external curricular force which should be dealt with one way or another and not as an important tool for success in students' future life. Another piece of evidence which can be presented in support of this claim is the fact that only small and statistically insignificant decreases were identified in 'ought-to L2 self' and 'instrumental-prevention' which are both more extrinsic rather than intrinsic. Therefore, we may claim that the context is more in favour of extrinsic motivational forces rather than the intrinsic types. This finding also reveals that we may not expect learner autonomy to develop in such a context as previous studies have suggested fostering learner autonomy is connected with the more internal types of motivation (e.g. Ushioda, 2011). Within the same motivational self system, however, the rate of 'cultural orientations' remained almost unchangeably high which indicates the curriculum has little effect on students' 'attitudes towards L2 community and cultural interest'.

Another finding of the study which can be interpreted within the context of English language teaching is the level of 'L2 anxiety' which increases, although not significantly, during the last years of high school. According to the results, students should generally feel more anxious to speak in English after they graduate from high school. Papi (2010) found that while 'ideal L2 self' and 'L2 learning experience' decrease 'L2 anxiety', 'ought-to L2 self' increases 'L2 anxiety' among English learners. Therefore, with the statistically significant decrease in 'ideal L2 self' and only a small and insignificant decrease in 'ought-to L2 self', we should not expect to see a decrease in L2 anxiety. This is supported in the finding of the present research as we saw that the rate of 'L2 anxiety' increases during the last years while the rate of motivational variables including 'ideal L2 self' declines. This finding in addition to the fact that the more internal kinds of motivation are significantly lower seem to indicate that the context does not motivate learners to acquire the foreign language effectively.

\section{Conclusions}

The present study examined the effects of environmental factors on the 'L2 Motivational Self System' of 
Motivational changes of learners in a traditional context of English education

English language learners after four years of learning English at high schools in Iran. On the basis of the obtained results, we may come to the conclusion that the educational environment negatively affects all the motivational orientations and the more internal sources of motivation are more severely impacted. In addition, 'L2 anxiety' has been shown to increase, although not significantly, in the last years of high school English language teaching. The results are to a great extent similar to the findings of research carried out by Farhady (2006) who reported an almost similar declining trend in the motivation of learners from the second to the third grade of junior high schools in Iran.

The changes in the motivational measures investigated in the present study show the effects of an educational context in which traditional approaches and conservative policies of foreign language teaching dominate foreign language classes. The results have implications for policy makers, English language teachers, textbook writers and test developers because the motivational changes reflect the effects of various EFL program components in the present situation of English language teaching in Iran. Obviously, maximizing the role of different motivational variables and preparing the context for effective learning of English at high school requires reforms in various components of the program. Since different educational variables including characteristics of teachers, classroom materials, classroom environment, etc have been shown to be related to learner motivation (e.g. Falout \& Maruyama, 2004; Gorham \& Christophel, 1992; Kikuchi \& Sakai, 2009), it can be suggested that these components of the program should be changed scientifically so that the system can engage the learners and motivate them to learn the language.

\section{References:}

Coetzee-Van Rooy, S. (2006), Integrativeness: untenable for world Englishes learners? World Englishes, 25, 437-450. <http://dx.doi.org/10.1111/j.1467-971X.2006.00479.x>

Crooks, G., \& Schmidt, R. (1991). Motivation: Reopening the research agenda. Language learning, 41, 469-512. $<$ http://dx.doi.org/10.1111/j.1467-1770.1991.tb00690.x>

Dastgheib, A. (1996). The role of attitudes and motivation in second/foreign language learning. Unpublished doctoral dissertation, Islamic Azad University-Tehran.

Deci, E. L., \& Ryan, R. M. (1985). Intrinsic motivation and self-determination in human behavior. New York: Plenum.

Dörnyei, Z. (1994). Motivation and motivating in foreign language classroom. Modern Language Journal, 78, 273-284.

Dörnyei, Z. (2000). Motivation in action: Towards a process-oriented conceptualization of student motivation. British Journal of Educational Psychology, 70, 519-538. <http://dx.doi.org/10.1348/000709900158281>

Dörnyei, Z. (2001). Teaching and researching motivation. Harlow: Longman.

Dörnyei, Z. (2005). The psychology of the language learner: Individual differences in second language acquisition. Mahwah, NJ: Lawrence Erlbaum.

Dörnyei, Z., \& Csizér, K. (2002). Some dynamics of language attitudes and motivation: Results of a longitudinal nationwide survey. Applied Linguistics, 23, 421-462. <http://dx.doi.org/10.1093/applin/23.4.421>

Dörnyei, Z., \& Ushioda, E. (2009). Motivation, language identities and the L2 self: Future research directions. In Z. Dörnyei \& E. Ushioda (Eds.), Motivation, language identity and the L2 self (pp. 350-356). Clevedon, UK: Multilingual Matters.

Falout, J., \& Maruyama, M. (2004). A comparative study of proficiency and learner demotivation. The Language Teacher, 28, 3-9.

Farhady, H. (2006). Evaluation of students' English language achievement in Iranian junior high schools. In H. Farhady (Ed.), Twenty-five years of living with applied linguistics: Collection of articles (pp. 432-452). Rahnama Press, Tehran.

Farhady, H., Hezaveh, F. S., \& Hedayati, H. (2010). Reflections on foreign language education in Iran. TESL-EJ, 13, 1-18. Retrieved September 21, 2011, from http://tesl-ej.org/pdf/ej52/a1.pdf. 
Kiany, G. R., Mahdavy, B., \& Ghafar Samar, R.

Gardner, R. C. (1985). Social psychology and second language learning: The role of attitudes and motivation. London: Edward Arnold.

Gardner, R. C., \& Lambert, W. E. (1972). Attitudes and motivation in second language learning. Rowley, MA: Newbury House.

Gardner, R. C., Smythe, P. C., Clement, R., \& Gliksman, L. (1976). Second language acquisition: A social psychological interpretation. The Canadian Modern Language Review, 32, 198-213.

Hickey, D. T., \& McCaslin, M. (2001). A comperative sociocultural analysis of context and motivation. In S. Volet, \& S. Jarvela (Eds.), Motivation in learning contexts: Theoretical advances and methodological implications (pp. 33-55). Oxford: Pergamon.

Higgins, E. T. (1987). Self-discrepancy: A theory relating self and affect, Psychological Review, 94, 319-40. <http://dx.doi.org/10.1037/0033-295X.94.3.319>

Higgins, E. T. (1998). Promotion and prevention: Regulatory focus as a motivational principle1, Advances in Experimental Social Psychology, 30, 1-46. <http://dx.doi.org/10.1016/S0065-2601(08)60381-0>

Jones, F., \& Jones, L. (2000). Comprehensive classroom management: Creating communities of support and solving problems. Needham Heights, MA: Allyn \& Bacon.

Kikuchi, K., \& Sakai, H. (2009) Japanese learners' demotivation to study English: A survey study. JALT Journal, 31, 183-204.

Kirkgöz, Y. (2007). English language teaching in Turkey. RELC Journal, 38, 216-228. $<$ http://dx.doi.org/10.1177/0033688207079696>

Kirkgoz, Y. (2009). Globalization and English language policy in Turkey. Educational Policy, 23(5), 663-684. <http://dx.doi.org/10.1177/0895904808316319>

Lamb, M. (2004). Integrative motivation in a globalizing world. System, 32, 3-19. $<$ http://dx.doi.org/10.1016/j.system.2003.04.002>

Legenhausen, L. (1999). The emergence and use of grammatical structures in conversational interactions; comparing traditional and autonomous learners. In B. Mißler \& U. Multhaup (Ed.), The construction of knowledge, learner autonomy and related issues in foreign language learning (pp. 27-40). Tübingen: Stauffenburg.

MacIntyre, P. D., \& Gardner, R. C. (1994). The subtle effects of language anxiety on cognitive processing in the second language. Language Learning, 44, 283-305. $<$ http://dx.doi.org/10.1111/j.1467-1770.1994.tb01103.x>

Markus, H., \& Nurius, P. (1986). Possible selves. American Psychologist, 41, 954-969. <http://dx.doi.org/10.1037/0003-066X.41.9.954>

Matin, M. (2007). The relationship between attitudes and orientation toward English learning and preferences in the use of language learning strategies. Unpublished master's thesis, Iran University of Science and Technology, Tehran, Iran.

Mcrobbie, C., \& Tobin, K. (1995) Restraints to reform: The congruence of teacher and student actions in a chemistry classroom. Journal of Research in Science Teaching, 32, 373-385. $<$ http://dx.doi.org/10.1002/tea.3660320406>

Namaghi, O. (2010). Parameters of language teaching in the context of high schools of Iran: A data-first approach. Asian EFL, 12, 213-23.

Noels, K. A., Pelletier, L., Clément, R., \& Vallerand, R. (2000). Why are you learning a second language? Motivational orientations and self-determination theory. Language Learning, 50, 57-85. <http://dx.doi.org/10.1111/0023-8333.00111>

Papi, M. (2010). The L2 motivational self system, L2 anxiety, and motivated behavior: A structural equation modelling approach. System, 38, 467-479. <http://dx.doi.org/10.1016/j.system.2010.06.011>

Philippe, F. L., \& Vallerand R. J. (2008). Actual environments do affect motivation and psychological adjustment: A test of self-determination theory in a natural setting. Motivation and Emotion, 32, 81-89. $<$ http://dx.doi.org/10.1007/s11031-008-9087-z>

Riazi, A. M. (2005). The four language stages in the history of Iran. In A. M.Y. Lin \& P. W. Martin (Eds.), Decolonization, globalization: Language-in-education policy and practice (pp. 100-116). Clevedon, 
UK: Multilingual Matters.

Riazi, A., \& Mosalanejad, N. (2010). Evaluation of learning objectives in Iranian high school and pre-university English textbooks using Bloom's taxonomy. TESL-EJ, 13, 1-16. Retrieved April 18, 2011, from http://tesl-ej.org/pdf/ej52/a5.pdf

Sadighi, F., \& Maghsudi, N. (2000). The relationship between motivation and English proficiency among Iranian EFL learners. Indian Journal of Applied Linguistics, 26, 39-52.

Schmuck, R., \& Schmuck, P. (2001). Group processes in the classroom. Boston, MA: McGraw-Hill.

Tobin, K., \& Mcrobbie, C. (1996). Cultural myths as constraints to the enacted science curriculum. Science Education, 80(2), 223-241. <http://dx.doi.org/10.1002/(SICI)1098-237X(199604)80:2<223::AID-SCE6>3.0.CO;2-I>

Tremblay, P. F., \& Gardner, R. C. (1995). Expanding the motivation construct in language learning. The Modern Language Journal, 79, 505-518. <http://dx.doi.org/10.1111/j.1540-4781.1995.tb05451.x>

Taguchi, T., Magid, M., \& Papi, M. (2009). The L2 motivational self system amongst Chinese, Japanese, and Iranian learners of English: A comparative study. In Z. Dörnyei \& E. Ushioda (Eds.), Motivation, language identity and the L2 self (pp. 66-97). Clevedon, UK: Multilingual Matters.

Ushioda, E. (2011). Motivating learners to speak as themselves. In G. Murray, X. Gao, \& T. Lamb (Eds.), Identity, motivation and autonomy in language learning (pp. 11-24). Bristol: Multilingual Matters.

Vaezi, Z. (2008). Language learning motivation among Iranian undergraduate students. World Applied Sciences Journal, 5, 54-61.

Wang, W., \& Lam A. S. L. (2009). The English language curriculum for senior secondary school in China: Its evolution from 1949. RELC Journal, 40, 65-82. <http://dx.doi.org/10.1177/0033688208101447> 


\section{Motivation Items and factor loadings}

\begin{tabular}{lc}
\hline \multicolumn{1}{c}{ Items } & Loading \\
\hline Interest & .79 \\
37. I always look forward to English classes. & .79 \\
38. Would you like to have more English classes at school? & .78 \\
40. Do you really enjoy learning English? & .74 \\
17. If my teacher would give the class an optional assignment, I would certainly volunteer to do it. & .74 \\
39. How much do you like English? & .73 \\
5. I would like to spend lots of time studying English. & .73 \\
30. Do you find learning English really interesting? & .72 \\
21. I would like to study English even if I were not required to do so. & .70 \\
25. If an English course was offered in the future, I would like to take it. & .69 \\
24. I would like to concentrate on studying English more than any other topic. & .67 \\
9. I am prepared to expend a lot of efforts in learning English. & .65 \\
26. Do you like the atmosphere of your English classes? & .61 \\
34. Do you find time passes faster while learning English? &
\end{tabular}

\section{Ought-to L2 self}

19. I have to study English, because, if I don't do it, my parents will be disappointed with me.

16. Learning English is necessary because people surrounding me expect me to do so.

14. Studying English is important to me because, if I don't have knowledge of English, I'll be considered a weak learner.

12. Studying English is important to me in order to gain the approval of my peers/teachers/family/boss.

11. I consider learning English important because the people I respect think that I should do it.

23. Studying English is important to me, because I don't like to be considered a poorly educated person.

\section{Cultural orientations towards L2 community}

36. Do you like TV programs made in English-speaking countries? $\quad .80$

32. Do you like English films?

29. Do you like the people who live in English-speaking countries?

28. Do you like the music of English-speaking countries?

33. Do you like meeting people from English-speaking countries?

\section{Ideal L2 self}

10. I can imagine myself speaking English with international friends or colleges.

22. I can imagine myself living abroad and using English effectively for communicating with the locals.

20. Studying English is important to me because I am planning to study abroad.

4. Learning English is important to me because I would like to travel internationally

15. I can imagine myself studying in a university where all my courses are taught in English.

\section{Instrumental-promotion}

1. My parents/family believe(s) that I must study English to be an educated person. 64

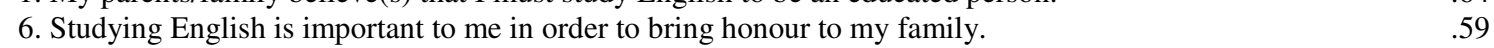

2. Studying English can be important to me because I think I'll need it for further studies.

13. Studying English is important to me in order to achieve a special goal (e.g., to get a degree or $\quad .55$ scholarship)

7. Studying English is important to me because English proficiency is necessary for promotion in the future.

\section{L2 Anxiety}

31. How uneasy would you feel speaking English with a native speaker?

27. How tense would you get if a foreigner asked you for directions in English?

\section{Instrumental-prevention}

3. I have to study English because I don't want to get bad marks in it. 